Sains Malaysiana 50(8)(2021): 2141-2152

http://doi.org/10.17576/jsm-2021-5008-01

\title{
Effects of Prohexadione Calcium Applications on Growth and Yield Characteristics of Cucumber (Cucumis sativus L.)
}

(Kesan Penggunaan Kalsium Proheksadion kepada Ciri Pertumbuhan dan Hasil Timun (Cucumis sativus L.)

\author{
HAKAN BAŞAK*
}

\section{ABSTRACT}

This study was conducted to determine the effects of growth regulator prohexadione calcium (Pro-Ca) and inhibitor gibberellic acid on some parameters (yield, pigment levels of leaves, nutrient contents, proline, enzyme activities and fruit quality) when applied at different doses $\left(0,15,30,45\right.$, and $\left.60 \mathrm{mg} \mathrm{L}^{-1}\right)$. Chemicals were applied after transplanting seedlings. A total of 12 plots including 3 plants for each dose were used in randomised plot experimental design. Although it has a positive effect on leaf proline content and enzyme activities, 45, and $60 \mathrm{mg} \mathrm{L}^{-1}$ doses of Pro-Ca had negative effects on morphological parameters (excluding stem diameter), yield, leaf pigment (excluding chlorophyll a) and nutrient contents compared to control. High Pro-Ca doses generally affected the fruit quality properties positively while $15 \mathrm{mg} \mathrm{L}^{-1}$ of Pro-Ca did not affect other parameters, except decreasing fruit yield. A $30 \mathrm{mg} \mathrm{L} L^{-1}$ of Pro-Ca dose was the most positive effective dose on the examined parameters. The highest vegetative development, yield, nutrient uptake and proline content were obtained from the plants subjected to $30 \mathrm{mg} \mathrm{L}^{-1}$ of Pro-Ca dose. Moreover, this dose increased fruit firmness, TSS, EC values and enzyme activities compared to control. Being an important quality criterion in cucumber storage after harvest, the weight loss rate $29.4 \%$ was lower in fruits obtained from the plant having 30 $\mathrm{mg} \mathrm{L^{-1 }}$ of Pro-Ca dose compared to that of the control plants. Therefore, $30 \mathrm{mg} \mathrm{L}^{-1}$ of Pro-Ca application, beside its positive effects on plant growth, yield and fruit quality, can be suggested for also increase shelf life of fruits in cucumber cultivation in greenhouse.

Keywords: Cucumber; fruit quality; growth; prohexadione calcium; yield

\section{ABSTRAK}

Penyelidikan ini dijalankan untuk mengkaji kesan penggunaan pengatur pertumbuhan kalsium proheksadion (Pro-Ca) dan perencat asid giberelik pada beberapa parameter (hasil, tahap pigmen daun-daun, kandungan nutrien, prolina, aktiviti enzim dan kualiti buah) apabila diaplikasikan pada dos yang berbeza (0, 15, 30, 45 dan $\left.60 \mathrm{mg} \mathrm{L}^{-1}\right)$. Bahan kimia diaplikasikan selepas pindah tanam anak-anak benih. Sejumlah 12 plot tanaman termasuk 3 tumbuhan untuk setiap dos telah digunakan dalam reka bentuk uji kaji plot rawak. Walaupun terdapat kesan positif pada kandungan prolina daun dan aktiviti enzim, dos Pro-Ca 45 dan $60 \mathrm{mg} \mathrm{L}^{-1}$ menunjukkan kesan negatif pada parameter morfologi (tidak termasuk diameter batang), hasil, pigmen daun (tidak termasuk klorofil a) dan kandungan nutrien berbanding dengan parameter terkawal. Dos Pro-Ca yang tinggi secara umumnya memberi kesan yang positif kepada kualiti buah manakala Pro-Ca dengan $15 \mathrm{mg} \mathrm{L}^{-1}$ tidak memberi kesan kepada parameter yang lain, kecuali penurunan hasil buah. Dos Pro-Ca 30 $m g L^{-1}$ menunjukkan dos yang paling positif pada parameter yang dikaji. Pembangunan vegetatif, hasil, pengambilan nutrien dan kandungan prolina yang tertinggi telah diperoleh daripada tumbuhan yang dikenakan dos Pro- Ca 30 $m g L^{-1}$. Malah, dos tersebut meningkatkan kepejalan buah, TSS, nilai EC dan aktiviti enzim jika dibandingkan dengan parameter terkawal. Penyimpanan timun selepas penuaian merupakan kriteria yang amat penting, kadar penurunan berat sebanyak 29.4\% adalah lebih rendah pada buah yang diperoleh daripada tumbuhan yang menerima dos Pro-Ca

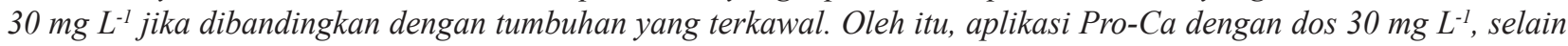
kesan positif terhadap pertumbuhan tumbuhan, hasil dan kualiti buah, ia juga menunjukkan peningkatan hayat simpan buah buahan dalam penuaian timun dalam rumah hijau.

Kata kunci: Hasil; kalsium proheksadion; kualiti buah; pertumbuhan; timun 


\section{INTRODUCTION}

The growth and development in plants are known to be regulated by hormones. Gibberellins (GAs) increase internode length by affecting both cell division and cell length (de Saint Germain et al. 2013). In order to control the vegetative growth in seedlings and their generative development, plant growth retardants (PGRs) such as daminozide, chlormequat chloride, uniconazole, ethephon, trinexapac-ethyl, paclobutrazole and prohexadionecalcium (Pro-Ca) are used (Demir \& Başak 2008; Ugur \& Kavak 2007). Since the cucumber fruits of parthenocarpic cultivars in greenhouse are formed in the leaf axillaries in internodes located on the stem, the short lengths between internodes provide more fruit per unit stem length. Therefore, cucumber plants with short lengths between the internodes are more yield than those with longer internodes.

Pro-Ca is a plant growth regulator that inhibits gibberellin biosynthesis, reducing vegetative growth and internode length (Kim et al. 2007). Pro-Ca is a new generation growth retardant, which inhibits dioxygenase enzymes activity (Dragisic-Maksimovic et al. 2017). Besides controlling growth in plants, Pro-Ca is a plant bio-regulators and plant protectant that improves yield and fruit quality. It was reported that Pro-Ca increased the yield and quality of Chinese cabbage grown in cold and humid conditions (Kang et al. 2010), decreased the frost damage in tomato fruits (Aghdam 2013). It also reduced the oxidative stress by increasing the synthesis of the flavonoids that reduce the production of reactive oxygen species (ROS) (Ghiasi \& Razavi 2013) and increased fruit weight, yield and leaf total soluble solids content in raspberry (Poledica et al. 2012).

Fard et al. (2015) observed that Pro-Ca treatment preserved the relative water content (RWC) and membrane stability in grass plants under drought stress. Bekheta et al. (2009) determined that proline, photosynthetic pigments, total carbohydrates and total soluble sugars were increased by Pro-Ca treatment in faba bean seedlings grown under salt stress, helping tolerance to stress conditions. It was reported that Pro-Ca preserved membrane integrity by reducing the accumulation of electrolyte leakage and malondialdehyde in tomato fruits, enhancing proline content and phenylalanine ammonia-lyase (PAL) enzyme activity and alleviating damage to cold after harvest (Aghdam 2013). With contributing to strengthening the natural defense mechanism by interfering with flavonoid metabolism in plants, Pro-Ca increases the level of luteoforol, a molecule with phytoalexin activity that increases resistance to pathogens (Spinelli et al. 2005).
Pro-Ca has a significant advantage compared to other PGRs due to its low toxicological effect and short half life in plants and soil (Bizjak et al. 2012). It was determined in different plant species that the application of lower doses of Pro-Ca in post-planting period had more positive effects on plant development, yield, and fruit quality compared to its higher doses (Altuntaş 2016; Kim et al. 2019).

Although many studies have been conducted to investigate the effectiveness of Pro-Ca application on cucumber seedlings in controlling growth and seedling quality, its effects on plant growth, yield and fruit quality after planting seedlings has not been sufficiently studied. . It was assumed that Pro-Ca, when applied to cucumber plants at lower doses after transplanting, may have positive effects on yield and fruit quality while it may reduce the lengths between the internodes in these plants. Thus, by using Pro-Ca, it was aimed to increase the yield and product quality to be obtained from the unit area. It is also expected that the positive effect of Pro-Ca on fruit quality can increase shelf life of cucumber fruits in storage and transport after harvest. Therefore, the effects of Pro-Ca applications at different doses to cucumber plants grown in cocopeat substrate with soilless agriculture technique on plant growth, yield, physiological properties and fruit quality were investigated in the current study.

\section{MATERIALS AND METHODS}

\section{EXPERIMENTAL CONDITIONS AND PRO-CA TREATMENTS}

This study was conducted in Soilless Agriculture Research Unit of Horticulture Department of Faculty of Agriculture of Kırşehir Ahi Evran University. Cevher $\mathrm{F}_{1}$ cucumber cultivar seedlings (obtained from Yüksel Seeds A.Ş, Antalya, Turkey) were used as plant material. Cucumber seedlings were planted in cocopeat slabs $(100 \times 20 \times 16 \mathrm{~cm})$ placed on $4 \mathrm{~m}$ long gutters on 27 April 2018. Each slab contained 3 plants. Pro-Ca (10\% prohexadione-calcium, Velonta WG, BASF, Germany) was sprayed onto plant leaves at $0,15,30,45$, and $60 \mathrm{mg}$ $\mathrm{L}^{-1}$ doses twice - on the $10^{\text {th }}$ day (on 7 May 2018); and on the $20^{\text {th }}$ day after planting seedling (17 May 2018) (Table 1). Each dose was one treatment. In the current study, Pro-Ca application was performed twice with an interval of 10 days based on the supplier's suggestion that 'Velonta' should be applied twice by the producers to better control shoot development and to increase fruit quality (BASF 2019).

For each treatment dose, 12 plots including 3 plants were used in randomised plot experimental design. The 
first and last plants of each gutter row were accepted as edge effects and discarded from the measurements and analyzes. The plants were irrigated with the $\mathrm{pH}$ and EC controlled automation system by changing their nutrient supply according to their requirements during development periods with some modifications in Hoagland nutrient solution (Table 2) (Gül et al. 2000). The range of plant nutrients was applied according to the growth of the plant.

TABLE 1. The chronological procedure of the current study

\begin{tabular}{lc}
\hline \multicolumn{1}{c}{ Procedure } & Date \\
\hline Planting seedlings & 27.04 .2018 \\
The first Pro-Ca application & 07.05 .2018 \\
The second application & 17.05 .2018 \\
The time (day) after Pro-Ca applications & 11.06 .2018 \\
On $25^{\text {th }}$ day, plant height and measurements of lengths between internodes & 06.07 .2018 \\
On $50^{\text {th }}$ day, plant height and measurements of lengths between internodes & 31.07 .2018 \\
On $75^{\text {th }}$ day, plant height and measurements of lengths between internodes & 25.08 .2018 \\
On $100^{\text {th }}$ day, completion of the experimental procedure of the study & \\
\hline
\end{tabular}

TABLE 2. Chemical contents of nutrient solution ( $\left.\mathrm{mg} \mathrm{L}^{-1}\right)$

\begin{tabular}{cccccccccccccc}
\hline Elements & $\mathrm{N}$ & $\mathrm{P}$ & $\mathrm{K}$ & $\mathrm{Ca}$ & $\mathrm{Mg}$ & $\mathrm{Fe}$ & $\mathrm{Mn}$ & $\mathrm{Zn}$ & $\mathrm{B}$ & $\mathrm{Cu}$ & $\begin{array}{c}\mathrm{EC} \\
\mathrm{Mo} \\
(\mathrm{mS} \\
\left.\mathrm{cm}^{-1}\right)\end{array}$ \\
\hline Concentration & $184-259$ & $29-46$ & $228-350$ & $152-190$ & $36-53$ & $2-3$ & $0.75-1.5$ & $0.5-1.0$ & 0.4 & $0.1-0.2$ & 0.05 & $1.8-2.4$ \\
\hline
\end{tabular}

\section{GROWTH AND YIELD}

At the end of the trial, 100 days after Pro-Ca applications (25 August 2018), plant height from soil level to shoot tip $(\mathrm{cm})$, length between internodes of the third node $(\mathrm{cm})$, stem diameter at $5 \mathrm{~cm}$ above ground level $(\mathrm{mm})$, plant fresh and dry weights $(\mathrm{g})$ were determined. The plant height and the length between internodes were measured for 15 plants selected from each Pro-Ca application group on the $25^{\text {th }}, 50^{\text {th }}$ and $75^{\text {th }}$ days (Table 1 ). All harvests made during the trial were weighed and recorded separately for each plant as yield per plant $\left(\mathrm{g} \mathrm{plant}^{-1}\right)$.

\section{POMOLOGICAL MEASUREMENT AND ANALYSIS}

To determine the flesh firmness, the fruit peel was removed from three different regions and the measurement was made in Newton $(\mathrm{N})$ unit using a penetrometer (PCE- 
FM200, Force Gauge) with a $7.9 \mathrm{~mm}$ tip. To determine total soluble solids (TSS), the juice of each cucumber was extracted and filtered on the filter paper, and the TSS was read as percent (\%) using digital refractometer (Hanna $\mathrm{HI} 96801)$. The $\mathrm{pH}$ and $\mathrm{EC}\left(\mathrm{dS} \mathrm{m}^{-1}\right)$ values of fruit juices were determined by using table type $\mathrm{pH}$ meter (HI522102 Hanna) and EC meter (Mettler Toledo MC-126), respectively. To determine their fresh weight, 20 fresh fruits were selected randomly for each application group at harvest. Then, the weight difference (weight loss) between fresh and stored fruit samples in the incubator at $20{ }^{\circ} \mathrm{C}$ for $120 \mathrm{~h}$ was determined using the following formula:

Weight loss $(\%)=$ the fruit weight $(\mathrm{g})$ of fruit after incubating at $20^{\circ} \mathrm{C}$ for $120 \mathrm{~h} \times 100 /$ fresh fruit weight $(\mathrm{g})$.

\section{LEAF PIGMENT ANALYSIS}

The leaf pigment contents were determined according to the method of Arnon (1949). Fresh leaf tissues (200 mg) were homogenized in acetone (80\%). Homogenates were centrifuged and the absorbances of supernatants were determined at $645,652,663$, and $470 \mathrm{~nm}$. The amounts of pigments were calculated according to the formula of Lichtenthaler and Wellburn (1983).

\section{MINERAL ANALYSIS}

Nitrogen content was determined by Kjeldahl method (Bremner 1965). Phosphorus (P) was quantified by vanadomolybdophosphoric acid colorimetric method. The $\mathrm{K}, \mathrm{Ca}, \mathrm{Mg}, \mathrm{Fe}, \mathrm{Zn}, \mathrm{Mn}$ and $\mathrm{Cu}$ contents were determined using an AAS (Atomic Absorption Spectrophotometer) (Kacar \& Inal 2008).

\section{ANTIOXIDATIVE ENZYMES AND PROLINE ANALYSIS}

Superoxide dismutase (SOD) activity was assayed spectrophotometrically as the inhibition of photochemical reduction of nitroblue tetrazolium (NBT) at $560 \mathrm{~nm}$ according to Beauchamp and Fridovich (1971). Peroxidase (POD) activity was assayed by measuring the rate change in absorbance at $470 \mathrm{~nm}$ using the method of Omran (1980). Catalase (CAT) enzyme activity was determined by measuring the initial rate of $\mathrm{H}_{2} \mathrm{O}_{2}$ disappearance at $240 \mathrm{~nm}$ using the extinction coefficient (Aebi 1984). The proline content $\left(\mu \mathrm{g} \mathrm{g}^{-1} \mathrm{FW}\right)$ was determined according to Bates et al. (1973).

\section{STATISTICAL ANALYSIS}

The data were analysed by GLM procedure of SPSS (Windows Version SPSS, release 20.00). Means were compared with Duncan's Multiple Range test in the same software.

\section{RESULTS AND DISCUSSION}

\section{GROWTH PARAMETERS}

According to plant height measurements on $25^{\text {th }}, 50^{\text {th }}$, $75^{\text {th }}$, and $100^{\text {th }}$ days after initiation of the study, Pro-Ca applications affected plant height significantly $(\mathrm{P}<0.001)$ (Figure 1). The plants subjected to Pro-Ca doses 45 and $60 \mathrm{mg} \mathrm{L}^{-1}$ were shorter than the control plants at all height measurement times $(\mathrm{P}=0.000)$. The plants with $15 \mathrm{mg} \mathrm{L}^{-1}$ Pro-Ca were shorter than the control on the $25^{\text {th }}$ and $50^{\text {th }}$ days, but this difference disappeared on the $75^{\text {th }}$ day and afterwards. The higher plant length was obtained in the plants having $30 \mathrm{mg} \mathrm{L}^{-1}$ Pro-Ca and control on the $25^{\text {th }}$ and $50^{\text {th }}$ days after application. Only plants with 30 $\mathrm{mg} \mathrm{L}{ }^{-1}$ Pro-Ca dose were higher on the $75^{\text {th }}$ and $100^{\text {th }}$ days compared to the plants with other doses.

The reduction effect of Pro-Ca at 45 and $60 \mathrm{mg} \mathrm{L}^{-1}$ on the length between the internodes was higher than other doses, but this effect partially disappeared on $100^{\text {th }}$ day in $45 \mathrm{mg} \mathrm{L}^{-1}$ Pro-Ca treatment (Figure 2). Plants with 15 $\mathrm{mg} \mathrm{L}^{-1}$ Pro-Ca and the control had similar length between thier internodes statistically at all measurement times. On the $25^{\text {th }}$ day, the length between internodes in $30 \mathrm{mg} \mathrm{L}^{-1}$ Pro-Ca plants was lower than the control. However, this difference was small on the $50^{\text {th }}$ day and higher than the control plants on the $75^{\text {th }}$ day.

The effect of Pro-Ca on stem diameter was dose dependent (Table 3). Along with the increase in Pro-Ca doses, an increase in the stem diameter was determined, and the highest stem diameter $(11.01 \mathrm{~mm})$ was obtained by $60 \mathrm{mg} \mathrm{L}^{-1}$ Pro-Ca application. Fresh stem weight was decreased by Pro-Ca applications, but the plants with $30 \mathrm{mg} \mathrm{L}^{-1}$ Pro-Ca had fresh stem weights similar to those of the control plants $(\mathrm{P}<0.05)$. Among all applications, the highest fresh stem weight was $945.7 \mathrm{~g}$ in plants subjected to $30 \mathrm{mg} \mathrm{L}^{-1}$ Pro-Ca. Similarly, the highest dry stem weight was $102.5 \mathrm{~g}$ in plants subjected to $30 \mathrm{mg}$ $\mathrm{L}^{-1}$ Pro-Ca (Table 3). However, the dry stem weight in 45 and $60 \mathrm{mg} \mathrm{L}^{-1}$ Pro-Ca applied plants did not decrease compared to the control as such the fresh stem weight, 
but on the contrary slight increase though not statistically significant. The effect of Pro-Ca, which is a gibberellic acid inhibitor, on plants has not always prevented growth and development. In some cases, the effect of Pro-Ca is growth promoting depending on plant species, growth stage, season, application dose and number.

Altıntaş (2011) reported that a low dose $50 \mathrm{mg} \mathrm{L}^{-1}$ of Pro-Ca increased plant height, while higher doses (100, 200 , and $300 \mathrm{mg} \mathrm{L}^{-1}$ ) decreased plant height significantly. Altuntas (2016) stated that the highest plant height and stem diameter were obtained in tomato plants subjected to $15 \mathrm{mg}$ Pro-Ca against other application doses $(0,5$, 30, and $\left.45 \mathrm{mg} \mathrm{L}^{-1}\right)$. Kim et al. (2010) determined Pro-Ca doses $\left(100,200\right.$, and $\left.400 \mathrm{mg} \mathrm{L}^{-1}\right)$ caused decreases in plant height and length between internodes in Chrysanthemum morifolium R. cv Monalisa White compared to control.

Because of effect on gibberellin inhibition, Pro-Ca decreased plant height and length between internodes of tomatoes (Altıntaş 2011), onion (El-Ghorab et al. 2019), strawberries (Kim et al. 2019) and eggplant (Özbay \& Ergun 2015) without decreasing the number of leaves. In the current study, the similar observations were obtained until on the $50^{\text {th }}$ day in $30 \mathrm{mg} \mathrm{L}^{-1}$ Pro-Ca dose and until the end of the trial in 45 and $60 \mathrm{mg} \mathrm{L}^{-1}$ Pro-Ca doses. Altuntaş (2016) reported that Pro-Ca doses applied to tomato plants at different growthy stages increased plant fresh and dry weights, and the highest values were obtained at the dose $30 \mathrm{mg} \mathrm{L}^{-1}$ Pro-Ca as observed in this study.

Similar to the findings in this study, Akdemir (2018) study in lettuce seedlings showed that the higher doses (100 and $150 \mathrm{mg} \mathrm{L}^{-1}$ ) of Pro-Ca increased stem diameter and decreased plant height and stem fresh weight, while the low dose (50 $\left.\mathrm{mg} \mathrm{L}^{-1}\right)$ Pro-Ca increased stem fresh weight. Kim et al. (2019) reported that $50 \mathrm{mg} \mathrm{L}^{-1}$ Pro-Ca application after planting increased fresh and dry weights of strawberry plant compared to control.

Although the effect of Pro-Ca on vegetative growth inhibiton depends on its application doses, when the application is continued for 3-4 weeks, the inhibition of endogenous GA biosynthesis may decrease, and consequently vegetative growth accelerates again. Compared to control, the suppressive effects of Pro-Ca on growth parameters was low at lower doses 15 and 30 $\mathrm{mg} \mathrm{L}{ }^{-1}$, but was high at higher doses 45 and $60 \mathrm{mg} \mathrm{L}^{-1}$. According to the present findings, it can be said that Pro-Ca blocks cell elongation, but not cell division. At 45 and $60 \mathrm{mg} \mathrm{L}^{-1}$ doses, plant height and length between internodes decreased compared to control, though the stem diameter, fresh and dry stem weights increased. This may be due to Pro-Ca's decreasing effect on gibberellic acid level in apical meristems and its increasing effect on cytokine level.

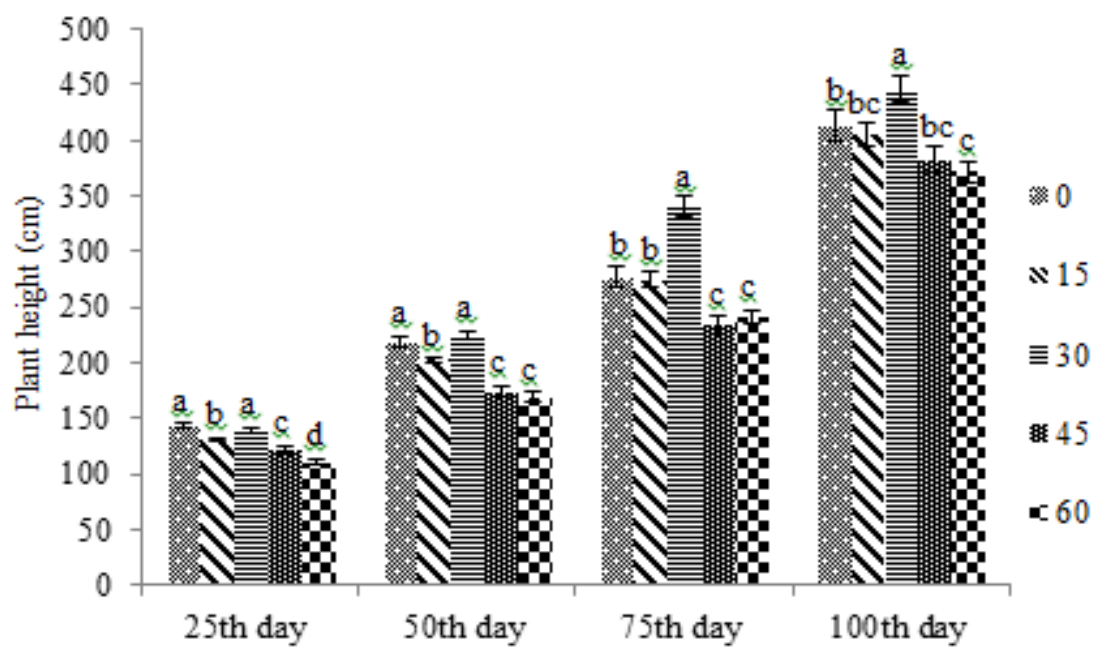

FIGURE 1. The effects of Pro-Ca $\left(\mathrm{mg} \mathrm{L}^{-1}\right)$ treatments on plant height 


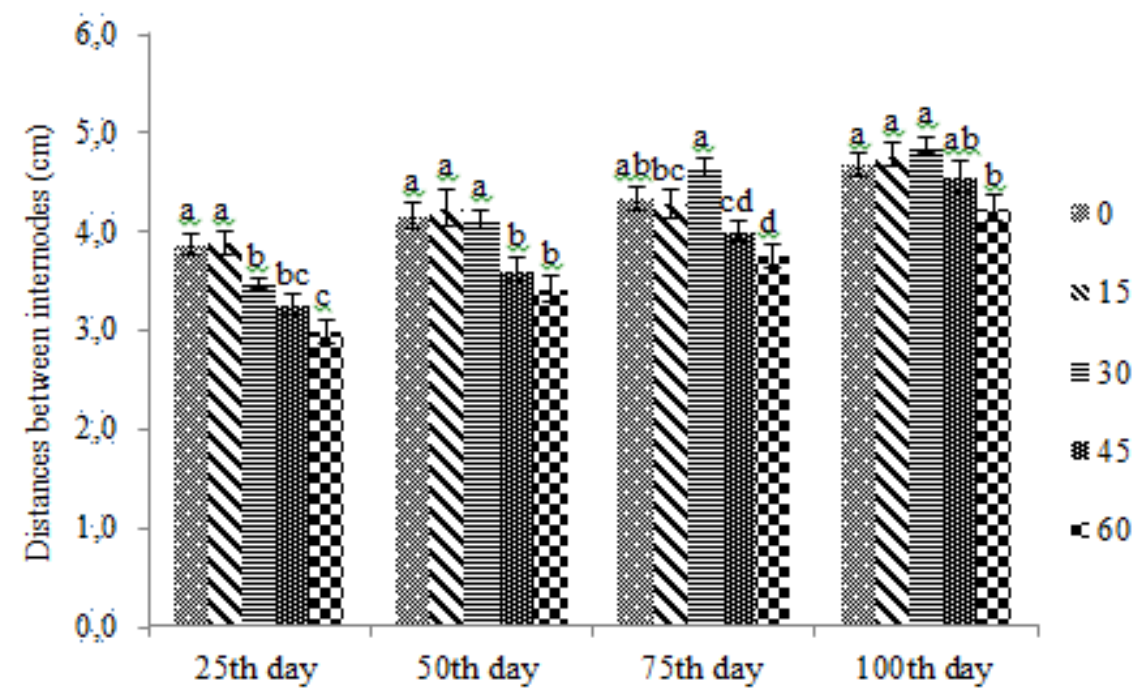

FIGURE 2. The effects of Pro-Ca $\left(\mathrm{mg} \mathrm{L}^{-1}\right)$ treatments on the lengths between internodes

TABLE 3. The effects of Pro-Ca treatments on stem diameter, fresh and dry stem weights

\begin{tabular}{lccccccc}
\hline & \multicolumn{7}{c}{ Pro-Ca treatments $\left(\mathrm{mg} \mathrm{L}^{-1}\right)$} \\
& 0 & 15 & 30 & 45 & 60 & SEM & P \\
\hline Stem diameter $(\mathrm{mm})$ & $9.57 \mathrm{c}^{*}$ & $9.71 \mathrm{bc}$ & $10.16 \mathrm{abc}$ & $10.56 \mathrm{ab}$ & $11.01 \mathrm{a}$ & 0.142 & 0.005 \\
Stem fresh weights $(\mathrm{g})$ & $892.5 \mathrm{ab}$ & $826.8 \mathrm{abc}$ & $945.7 \mathrm{a}$ & $728.6 \mathrm{c}$ & $757.9 \mathrm{bc}$ & 23.10 & 0.012 \\
Stem dry weights $(\mathrm{g})$ & $84.19 \mathrm{~b}$ & $82.63 \mathrm{~b}$ & $102.47 \mathrm{a}$ & $86.63 \mathrm{~b}$ & $88.59 \mathrm{~b}$ & 2.08 & 0.017 \\
\hline
\end{tabular}

*Means in each row with the different letters are significantly different $(\mathrm{P}<0.05)$

\section{FRUIT QUALITY}

Fruit firmness was increased by Pro-Ca application. Fruit firmness in the plants subjected to 30,45 , and $60 \mathrm{mg} \mathrm{L}^{-1}$ Pro-Ca doses was significantly higher than those of the control and $15 \mathrm{mg} \mathrm{L}^{-1}$ Pro-Ca applied plants $(\mathrm{P}<0.001)$ (Table 4). Pro-Ca doses increased significantly TSS, $\mathrm{pH}$ and EC values of cucumber fruit juice compared to those of the control $(\mathrm{P}<0.001)$. Among all Pro-Ca doses, the highest TSS value (4.05\%) was obtained in $45 \mathrm{mg} \mathrm{L}^{-1}$ dose, the highest $\mathrm{pH}$ value (5.82) was in $60 \mathrm{mg} \mathrm{L}^{-1}$ dose, and the highest EC value $\left(4.50 \mathrm{dS} \mathrm{m}^{-1}\right)$ in $30 \mathrm{mg} \mathrm{L}^{-1}$ Pro-Ca. Pro$\mathrm{Ca}$ doses reduced the weight loss in cucumber fruits kept after harvest, except $15 \mathrm{mg} \mathrm{L}^{-1}$ dose. Among all Pro-Ca doses, the lowest weight loss $(20.1 \%)$ in cucumber fruits was obtained in $30 \mathrm{mg} \mathrm{L}^{-1}$ Pro-Ca (Table 4). The observed weight losses in cucumber fruits were 29.4 , 6, and $11.7 \%$ 
lower in the 30,45 , and $60 \mathrm{mg} \mathrm{L}^{-1}$ Pro-Ca doses than that of the control, respectively. Similar to the findings in this study, Altuntaş (2016) reported that Pro-Ca increased tomato fruit firnmess by obtaining the highest value at 30 $\mathrm{mg} \mathrm{L}^{-1}$ dose. Kang et al. (2010) reported that the increase of Pro-Ca doses increased the quality of Chinese cabbage by increasing total soluble sugar content and leaf hardness. Cucumber fruits have high $\mathrm{Ca}$ and $\mathrm{K}$ contents, increasing cell wall thickness and water holding capacity, extending the shelf life of fruits after harvest (Kaptan \& Aydın 2007). In the current findings, the increase of Ca content in plants by application of 30, 45, and $60 \mathrm{mg} \mathrm{L}^{-1}$ Pro-Ca doses increased significantly fruit firmness compared to the control. Moreover, these dose positive effects on cell wall thickness and resistance to stress reduced postharvest weight losses. Altuntaş (2016) reported that Pro-Ca increased TSS contents of tomato fruits without statistical significance, and numerically higher values were obtained by 15 and $45 \mathrm{mg} \mathrm{L}^{-1}$ doses. The increase in the total sugar and organic acid increases the taste and aroma in fruits. Pro-Ca decreases the amylase enzyme activity in plants and increases the total soluble sugar content of both fruit, and thus improves fruit quality (Rademacher et al. 2004).

The $\mathrm{pH}$ of fruit juice is an effective factor on taste of product. In vegetables, the $\mathrm{pH}$ is generally higher than 4.5. At low $\mathrm{pH}$ level, sourness increases in product. The products with high sugar content have low $\mathrm{pH}$ (Brown 2007). In the present findings, the increased $\mathrm{pH}$, TSS and EC values by Pro-Ca applications contributed to taste and aroma, and consequently increased fruit quality.

\section{FRUIT YIELD}

The effect of Pro-Ca on yield was found to be variable. The highest yield per plant (9182.1 g) was obtained with $30 \mathrm{mg} \mathrm{L}^{-1}$ of Pro-Ca. Yields of plants in other Pro-Ca doses were lower than the control $(7976.9 \mathrm{~g})(\mathrm{P}<0.001)$ (Figure 3). It was reported that Pro- $\mathrm{Ca}$ increased productivity by affecting basic physiological events such as photosynthesis in different plant species besides growth inhibition. Consistent with the present findings, Özbay and Ergun (2015) reported that higher Pro-Ca doses (100 and $150 \mathrm{mg} \mathrm{L}^{-1}$ ) decreased yield in eggplant, but no yield loss was seen with $50 \mathrm{mg} \mathrm{L}^{-1}$ dose. The study of tomato showed that increase in Pro-Ca application dose and its application number significantly reduced total yield and early yield (Altıntaş 2011).

Asin et al. (2007) reported that Pro-Ca application suppresses growth with no negative effect on yield and flowering time. However, its positive effects on yield and fruit quality on apple and pear (Rademacher et al. 2004), tomato strawberry (Poledica et al. 2012) and onion (ElGhorab et al. 2019) were reported. Kang et al. (2010) reported that Pro-Ca, when applied at different times and doses after planting, significantly increased yield by promoting growth parameters (head yield, leaf count, and head density) in Chinese cabbage.

Pro-Ca delays aging by reducing ethylene production by blocking 1-aminocyclopropane-1-carboxylate-oxidase (ACC-oxidase), an important enzyme in ethylene biosynthesis in plants. In the current study, when the general appearance of the plants were examined, it was observed that the plants treated with $30 \mathrm{mg} \mathrm{L}^{-1}$ Pro-Ca showed less signs of aging compared to the other doses.

Pro-Ca as a gibberellic acid inhibitor may therefore have increased the yield at a dose of $30 \mathrm{mg} \mathrm{L}^{-1}$. With the removal of the suppressive effect of $30 \mathrm{mg} \mathrm{L}^{-1}$, Pro-Ca on plant growth in the later stages increased nutrient intake, leaf pigmentation, proline content, enzyme activity, and photosynthesis ratio, triggering an increase in yield in tested plants.

\section{LEAF PIGMENTATION}

Pro-Ca affected leaf pigmentation in cucumber plants significantly $(\mathrm{P}<0.001)$. Chlorophyll a level was significantly higher in leaves of plants subjected to 30 , 45 and $60 \mathrm{mg} \mathrm{L}^{-1}$ doses of Pro-Ca compared to those of the control $(\mathrm{P}<0.001)$ (Table 5). Chlorophyll $b$ contents in the $15 \mathrm{mg} \mathrm{L}^{-1}$ and $30 \mathrm{mg} \mathrm{L}^{-1}$ Pro-Ca applied plants were similar to those of the control, while these contents were lower in the leaves of 45 and $60 \mathrm{mg} \mathrm{L}^{-1}$ Pro-Ca applied plants $(\mathrm{P}<0.001)$. The highest total chlorophyll content was obtained in $30 \mathrm{mg} \mathrm{L}^{-1}$ Pro-Ca dose with $5.312 \mathrm{mg} \mathrm{g}^{-1}$. The total chlorophyll contents were lower in the leaves of plants subjected to 45 and $60 \mathrm{mg} \mathrm{L}^{-1}$ Pro-Ca doses compared to that of the control. Similarly, the highest carotenoid content $\left(1.234 \mathrm{mg} \mathrm{g}^{-1}\right)$ was detected in plants treated with $30 \mathrm{mg} \mathrm{L}^{-1}$ Pro-Ca dose, but was decreased by 45 and $60 \mathrm{mg} \mathrm{L}^{-1}$ doses.

Kang et al. (2010) demonstrated significant decreases in leaf length and width with the effect of Pro-Ca applications but a significant increase in leaf chlorophyll content. The effect of Pro-Ca on leaf pigment level was dose dependent. In the current study, increases in chlorophyll $a / b$ ratio were obtained by the increasing Pro-Ca doses. The chlorophyll $a / b$ values were $1.98,2.05$, $2.18,3.68$, and 3.43 in control, 15, 30, 45, and $60 \mathrm{mg} \mathrm{L}^{-1}$ Pro-Ca doses, respectively. The increase in chlorophyll $a / b$ ratio is considered as a sign that the plants are resistant to 
stress conditions or away from stress (Chettri et al. 1998). The higher chlorophyll $a / b$ values obtained with higher Pro-Ca doses may suggest that Pro-Ca helps the resistance of plants to stress conditions.

Carotenoids act as antioxidants by protecting plant cells from the damage of superoxide and singlet oxygen released under stress conditions. In addition, carotenoids inhibit chlorophyll destruction by neutralizing free oxygen radicals (Edge \& Truscott 2018). In the present study, as in total chlorophyll contents, the caroteneoid contents were decreased at 45 and $60 \mathrm{mg} \mathrm{L}^{-1}$ doses compared to that of the control.

Kim et al. (2010) reported that leaf chlorophyll content was increased by Pro-Ca as the total leaf area decreased. Similar finding was obtained in the present study that the highest amount of fruit yield with total chlorophyll and carotenoid contents per plant was obtained by $30 \mathrm{mg} \mathrm{L}^{-1}$ Pro-Ca dose. In plants, leaf chlorophyll and carotenoid contents are directly affected by adequacy of the supply of nutrients. The present decreases in the chlorophyll and carotenoid contents in the leaves of plants subjected to 45 and $60 \mathrm{mg} \mathrm{L}^{-1}$ Pro-Ca could be explained by the decreases in the concentrations of $\mathrm{N}, \mathrm{P}$ and $\mathrm{K}, \mathrm{Mg}$ and $\mathrm{Fe}$. As well known, $\mathrm{Mg}$ is present in the structure of chlorophyll while Fe acts a role in its synthesis.

\section{LEAF NUTRIENT CONTENTS}

The effect of Pro-Ca on leaf nutrient contents was found to be significant (Table 6). The effects of Pro-Ca on concentrations of $\mathrm{N}, \mathrm{P}, \mathrm{K}, \mathrm{Mg}$, and Fe were similar. Higher concentrations of nutritional elements were observed in the leaves of plants subjected to $30 \mathrm{mg} \mathrm{L}^{-1}$ Pro$\mathrm{Ca}$, though there was no significant change in the leaves of plants subjected to $15 \mathrm{mg} \mathrm{L}^{-1}$ Pro-Ca. Pro-Ca significantly reduced the mineral contents in cucumber leaves at 45 and $60 \mathrm{mg} \mathrm{L}^{-1}$ doses, but it did not show effect at $15 \mathrm{mg}$ $\mathrm{L}^{-1}$ dose. However, $30 \mathrm{mg} \mathrm{L}^{-1}$ dose had positive efficacy on intakes of these minerals. Ca content in leaves was increased significantly by Pro-Ca applications, and it was dose dependent, especially at 30,45 , and $60 \mathrm{mg} \mathrm{L}^{-1}$ doses $(\mathrm{P}<0.000)$. The highest $\mathrm{Zn}$ content was found in plants applied with $30 \mathrm{mg} \mathrm{L}^{-1}$ Pro-Ca dose, but no significant reduction was observed in plants applied with 45 and $60 \mathrm{mg} \mathrm{L}^{-1}$ Pro-Ca dose. Mn content increased in leaves of plants applied with 30, 45, and $60 \mathrm{mg} \mathrm{L}^{-1}$ Pro-Ca doses compared to the control, while the highest $\mathrm{Mn}$ content was obtained by $30 \mathrm{mg} \mathrm{L}^{-1}$ Pro-Ca dose. Cu content was significantly decreased in 45 and $60 \mathrm{mg} \mathrm{L}^{-1}$ Pro-Ca doses $(\mathrm{P}<0.05)$, but not in the other doses.

Except for $15 \mathrm{mg} \mathrm{L}^{-1}$ dose, Pro-Ca doses increased $\mathrm{Ca}$ content in leaves. Ca has an active role on cell division, and it is present in plant cell membrane as pectate and phospahate forms. It is also involved in the transport of carbohydrates and amino acids in plants (Freitas et al. 2012). Therefore, the increase in Ca content in plants with 30, 45, and $60 \mathrm{mg} \mathrm{L}^{-1}$ Pro-Ca doses, most likely increased fruit firmness with plant growth and positively reduced post-harvest weight loss. It was reported that Pro-Ca application increased leaf nutrient contents, especially $\mathrm{Ca}$, Fe and Mn (Altuntaş 2016). Similarly in the present study, $\mathrm{Ca}$ and $\mathrm{Mn}$ contents in the plants subjected to Pro-Ca doses were observed higher than the control.

El-Ghorab et al. (2019) reported that Pro-Ca application at 10, 20, and $30 \mathrm{mg} \mathrm{L}^{-1}$ doses increased the $\mathrm{N}$, $\mathrm{P}, \mathrm{K}$ and $\mathrm{S}$ contents in onion, and this was more prominant for 20 and $30 \mathrm{mg} \mathrm{L}^{-1}$ doses. In the current study, $30 \mathrm{mg}$ $\mathrm{L}^{-1}$ Pro-Ca dose had the highest increasing effect on all analysed macro and micro elements except for $\mathrm{Cu}$. The high intakes of these elements, which are necessary for plant development, can be considered as one of the main reasons for positive contribution of $30 \mathrm{mg} \mathrm{L}^{-1}$ Pro-Ca dose to the other examined parameters.

\section{ENZYME ACTIVITIES AND PROLINE CONTENT}

Pro-Ca increased SOD, CAT, and POD enzyme activities by stimulating the antioxidative defense system in cucumber plants $(\mathrm{P}<0.001)$ (Table 7). Except for $15 \mathrm{mg} \mathrm{L}^{-1}$ dose, the increased Pro-Ca doses caused increases in these enzyme activities. While the highest SOD, CAT and POD activities were observed in plants applied with $60 \mathrm{mg}$ $\mathrm{L}^{-1}$ Pro-Ca dose, SOD, and POD activities were statistically similar in the plants treated with 45 and $60 \mathrm{mg} \mathrm{L}^{-1}$ doses. Compared to the control, SOD activity in plants treated with $30 \mathrm{mg} \mathrm{L}^{-1}$ Pro-Ca increased significantly, while the increase in CAT and POD activities was observed at a lower level. Except for $15 \mathrm{mg} \mathrm{L}^{-1}$ dose, Pro-Ca application doses increased the content of proline, which is an important osmoprotectant, similar to the effects of Pro-Ca effects on enzyme activities (Table 7). On the other hand, unlike on enzyme activities, the highest proline content (195.1 $\mu \mathrm{g}$ per $\mathrm{g}$ fresh weight) was obtained by $30 \mathrm{mg} \mathrm{L}^{-1}$ Pro$\mathrm{Ca}$. It was also observed that the highest dose of Pro-Ca decreased proline content, but it was still higher than that of the control. 
Antioxidant enzymes, as an important ROS detoxification system in plant cells, protect plants against oxidative stress (Zhang et al. 2012). El-Ghorab et al. (2019) reported that Pro-Ca had positive effects on growth, development, yield, mineral content, and antioxidant activity in onion plant. Fard et al. (2015) reported that Pro-Ca increased SOD, ascorbate peroxidase (APX) and CAT activities, which are the antioxidant enzymes, in turf plants grown under both well irrigated and drought conditions.

The observed high enzyme activities might be resulted from the stress caused by the application of 45 and $60 \mathrm{mg} \mathrm{L}^{-1}$ Pro-Ca doses since these high doses decreased leaf pigment level and nutrient contents. However, the positive effects of $30 \mathrm{mg} \mathrm{L}^{-1}$ Pro-Ca dose on plant growth, fruit yield and quality showed that this dose increased enzyme activities without causing any kind of stress. Also, the increase in the enzyme activities with this dose was reflected in positive plant growth and yield.

Aghdam (2013) reported that Pro-Ca increased proline content of tomato leaves. Bekheta et al. (2009) reported that Pro-Ca increased proline, photosynthetic pigments, total carbohydrates and total soluble sugars in faba bean seedlings grown under salt stress. Özbay and Süslüoğlu (2016) added Pro-Ca to the priming solution, and they observed an increase in germination performance of pepper seeds at low temperature by improving the proline, total carbohydrate and total soluble sugar content of the seeds. Borzouei et al. (2012) reported that the increase in SOD and proline levels increased resistance to stress conditions. Acting as an osmotic regulator between cytoplasm and vacuole, the proline contributes to the preservation of membrane integrity and protects plant tissues against stress conditions by detoxifying reactive oxygen species.

The increased leaf proline content with $30 \mathrm{mg} \mathrm{L}^{-1}$ of Pro-Ca increased nutrient uptake in plants due to proline's osmoregulator role. The increased pigment level in plants that feed better increases photosynthesis, and consequently increases in photosynthesis that increases both vegetative and reproductive (fruit yield) developments.

TABLE 4. The effects of Pro-Ca treatments on pomological characteristics of fruits

\begin{tabular}{|c|c|c|c|c|c|c|c|}
\hline \multicolumn{8}{|c|}{ Pro-Ca treatments $\left(\mathrm{mg} \mathrm{L}^{-1}\right)$} \\
\hline & 0 & 15 & 30 & 45 & 60 & SEM & $\mathrm{P}$ \\
\hline Fruit firmness $(\mathrm{N})$ & $46.24 b^{*}$ & $48.92 b$ & $55.63 \mathrm{a}$ & $57.70 \mathrm{a}$ & $55.26 \mathrm{a}$ & 1.019 & 0.000 \\
\hline $\mathrm{pH}(\%)$ & $5.68 \mathrm{c}$ & $5.79 \mathrm{ab}$ & $5.76 b$ & $5.75 b$ & $5.82 \mathrm{a}$ & 0.013 & 0.000 \\
\hline TSS $(\%)$ & $3.52 b$ & $3.92 \mathrm{a}$ & $3.95 \mathrm{a}$ & $4.05 \mathrm{a}$ & $3.98 \mathrm{a}$ & 0.048 & 0.000 \\
\hline $\mathrm{EC}\left(\mathrm{dS} \mathrm{m} \mathrm{m}^{-1}\right)$ & $3.53 \mathrm{c}$ & $3.98 b$ & $4.50 \mathrm{a}$ & $4.28 \mathrm{a}$ & $4.33 \mathrm{a}$ & 0.087 & 0.000 \\
\hline Weight loss (\%) & $28.45 \mathrm{a}$ & $28.83 \mathrm{a}$ & $20.10 \mathrm{~d}$ & $26.73 b$ & $25.11 \mathrm{c}$ & 0.620 & 0.000 \\
\hline
\end{tabular}

*Means in each row with the different letters are significantly different $(\mathrm{P}<0.05)$

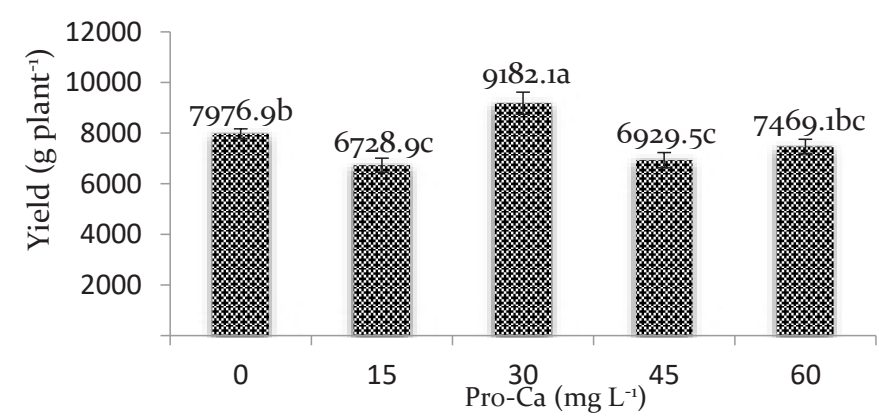

FIGURE 3. The effects of Pro-Ca treatments on yield (g plant ${ }^{-1}$ ) 
TABLE 5. The effects of Pro-Ca treatments on leaf pigmentation $\left(\mathrm{mg} \mathrm{g}^{-1} \mathrm{FW}\right)$

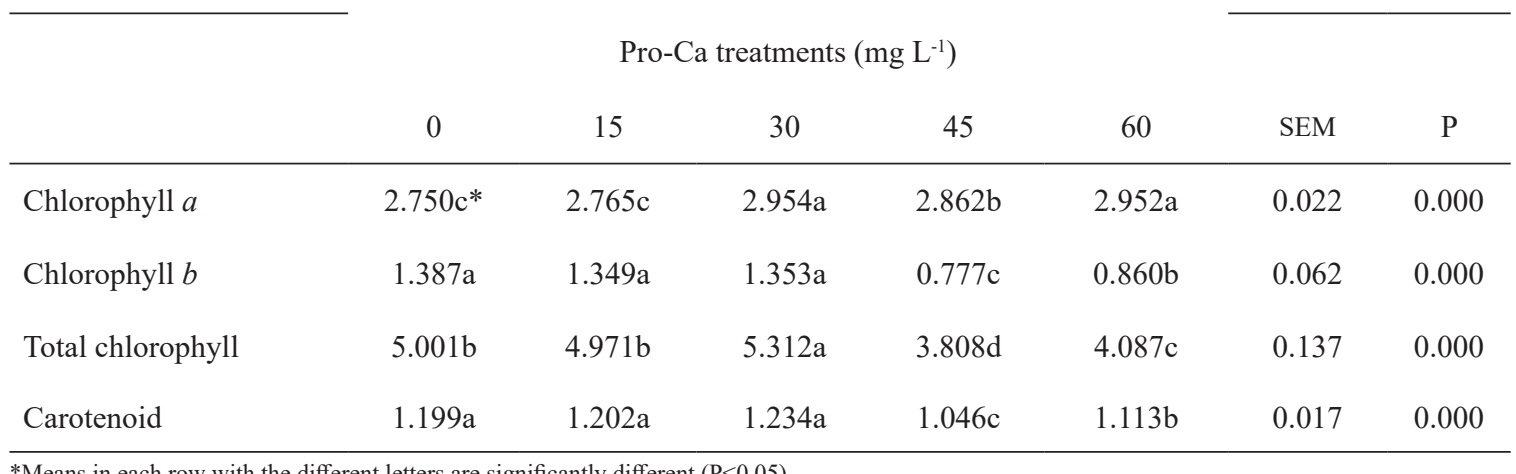

TABLE 6. The effects of Pro-Ca treatments on nutritional contents of cucumber leaves

\begin{tabular}{|c|c|c|c|c|c|c|c|c|c|}
\hline $\begin{array}{c}\text { Pro-Ca } \\
\left(\mathrm{mg} \mathrm{L}^{-1}\right) \\
(\mathrm{ppm})\end{array}$ & $\begin{array}{l}\mathrm{N} \\
(\%)\end{array}$ & $\begin{array}{c}\mathrm{P} \\
(\%)\end{array}$ & $\begin{array}{l}\mathrm{K} \\
(\%)\end{array}$ & $\begin{array}{l}\mathrm{Ca} \\
(\%)\end{array}$ & $\begin{array}{l}\mathrm{Mg} \\
(\%)\end{array}$ & $\begin{array}{c}\mathrm{Fe} \\
\left(\mathrm{mg} \mathrm{kg}^{-1}\right)\end{array}$ & $\begin{array}{c}\mathrm{Zn} \\
\left(\mathrm{mg} \mathrm{kg}^{-1}\right)\end{array}$ & $\begin{array}{c}\mathrm{Mn} \\
\left(\mathrm{mg} \mathrm{kg}^{-1}\right)\end{array}$ & $\begin{array}{c}\mathrm{Cu} \\
\left(\mathrm{mg} \mathrm{kg}^{-1}\right)\end{array}$ \\
\hline 0 & $3.196 b^{*}$ & $0.596 \mathrm{~b}$ & $4.185 b$ & $3.005 \mathrm{~b}$ & $0.435 b$ & $128.0 \mathrm{~b}$ & 46.42ab & $37.20 \mathrm{c}$ & $14.83 \mathrm{a}$ \\
\hline 15 & $2.943 b$ & $0.569 b$ & $4.015 b$ & $3.145 b$ & $0.413 b$ & $131.2 \mathrm{~b}$ & $42.79 b$ & $37.40 \mathrm{c}$ & $13.76 \mathrm{a}$ \\
\hline 30 & $3.842 \mathrm{a}$ & $0.683 a$ & $4.770 \mathrm{a}$ & $4.437 \mathrm{a}$ & $0.570 \mathrm{a}$ & $150.4 \mathrm{a}$ & $51.11 \mathrm{a}$ & $46.39 a$ & $13.79 a$ \\
\hline 45 & $2.250 \mathrm{c}$ & $0.420 \mathrm{c}$ & $3.330 \mathrm{c}$ & $4.400 \mathrm{a}$ & $0.278 \mathrm{c}$ & $94.9 \mathrm{c}$ & $45.50 \mathrm{ab}$ & $42.89 \mathrm{ab}$ & $10.38 \mathrm{~b}$ \\
\hline 60 & $2.057 \mathrm{c}$ & $0.473 \mathrm{c}$ & $3.220 \mathrm{c}$ & $4.460 \mathrm{a}$ & $0.326 \mathrm{c}$ & $107.7 \mathrm{c}$ & $39.06 \mathrm{~b}$ & $40.88 \mathrm{bc}$ & $10.25 b$ \\
\hline SEM & 0.154 & 0.227 & 0.145 & 0.172 & 0.249 & 5.069 & 1.295 & 1.046 & 0.553 \\
\hline $\mathrm{P}$ & 0.000 & 0.000 & 0.000 & 0.000 & 0.000 & 0.000 & 0.026 & 0.008 & 0.004 \\
\hline
\end{tabular}

*Means in each coloum with the different letters are significantly different $(\mathrm{P}<0.05)$

TABLE 7. The effects of Pro-Ca treatments on enzyme activities and proline content

\begin{tabular}{lcccccccc}
\hline & \multicolumn{9}{c}{ Pro-Ca treatments $\left(\mathrm{mg} \mathrm{L}^{-1}\right)$} & & \\
\cline { 2 - 6 } & 0 & 15 & 30 & 45 & 60 & SEM & P \\
\hline SOD $\left(\mathrm{U} \cdot \mathrm{g}^{-1} \mathrm{FW}\right)$ & $105.1 \mathrm{c}^{*}$ & $104.4 \mathrm{c}$ & $127.4 \mathrm{~b}$ & $146.3 \mathrm{a}$ & $149.3 \mathrm{a}$ & 4.721 & 0.000 \\
CAT $\left(\mathrm{U} \cdot \mathrm{g}^{-1} \mathrm{~min}^{-1}\right)$ & $21.84 \mathrm{c}$ & $23.61 \mathrm{c}$ & $27.71 \mathrm{bc}$ & $32.13 \mathrm{ab}$ & $34.89 \mathrm{a}$ & 1.355 & 0.001 \\
POD $\left(\mathrm{U} \cdot \mathrm{g}^{-1} \mathrm{~min}^{-1}\right)$ & $14.32 \mathrm{~b}$ & $14.50 \mathrm{~b}$ & $15.35 \mathrm{ab}$ & $16.14 \mathrm{a}$ & $16.24 \mathrm{a}$ & 0.260 & 0.027 \\
Proline $\left(\mu \mathrm{g} \cdot \mathrm{g}^{-1}\right)$ & $156.4 \mathrm{c}$ & $146.4 \mathrm{c}$ & $195.1 \mathrm{a}$ & $189.1 \mathrm{ab}$ & $175.6 \mathrm{~b}$ & 4.551 & 0.000 \\
\hline
\end{tabular}

* Means in each row with the different letters are significantly different $(\mathrm{P}<0.05)$ 


\section{CONCLUSION}

The present findings showed that Pro-Ca, which acts a gibberellic acid inhibitor not only shortens cell length, but also has positive effects on plant growth, yield and fruit quality at appropriate dosage and administration time. It was also showed that Pro-Ca application can increase the tolerance of biotic and abiotic stress conditions in plants by activating the enzymatic antioxidant defense system and increasing leaf proline content. To conclude, a $30 \mathrm{mg} \mathrm{L}^{-1}$ of Pro-Ca application had positive effects on cucumber plant growth, yield and fruit quality. Therefore, this Pro-Ca dose can be used in greenhouse cucumber cultivation to reduce post-harvest weight loss and increase storage and transport time of cucumber fruits with short shelf life.

\section{REFERENCES}

Aebi, H. 1984. Catalase in vitro. Methods in Enzymology 105: 121-126.

Aghdam, M.S. 2013. Mitigation of postharvest chilling injury in tomato fruit by prohexadione calcium. Journal of Agriculture and Food Technology 50(5): 1029-1033.

Akdemir, S. 2018. Effects of paclobutrazol and prohexadionecalcium applications on lettuce (Lactuca sativa L.) seedlings quality and plant growth. Ahi Evran University. MSc Thesis (Unpublished).

Altuntaş, Ö. 2016. The effects of prohexadione-Ca threatments on plant growth, nutrient elements uptake and fruit quality in tomato. Yuzuncu Yll University Journal of Agricultural Sciences 26(1): 98-105.

Altıntaş, S. 2011. Effects of prohexadionecalcium with three rates of phosphorus and chlormequat chloride on vegetative and generative growth of tomato. African Journal of Biotechnology 75: 17142-17151.

Arnon, D.I. 1949. Copper enzymes in isolated chloroplasts. Polyphenoloxidase in Beta vulgaris. Plant Physiology 24(1): $1-15$.

Asin, L., Alegre, S. \& Montserrat, R. 2007. Effect of paclobutrazol, prohexadione-Ca, deficit irrigation, summer pruning and root pruning on shoot growth, yield, and return bloom, in a 'Blanquilla' pear orchard. Scientia Horticulturae 113(2): 142-148.

BASF. 2019. Agricultural Solutions. https://www.agro.basf.com. $\operatorname{tr} /$ tr/Ürünler/Ürün Bilgileri/Velonta®-TR.html. Accessed on 10 Febuary 2018.

Bates, L.S., Waldren, R.P. \& Teare, I.D. 1973. Rapid determination of free proline for water stress studies. Plant and Soil 39(1): 205-207.

Beauchamp, C. \& Fridovich, I. 1971. Superoxide dismutase: Improved assay and an assay applicable to acrylamide gels. Analytical Biochemistry 44(1): 276-287.

Bekheta, M.A., Abdelhamid, M.T. \& El-Morsi, A.A. 2009. Physiological response of Vicia faba to prohexadionecalcium under saline conditions. Planta Daninha 27(4): 769-779.
Bizjak, J., Jakopic, J., Slatnar, A., Stampar, F., Stich, K., Halbwirth, H., Zadravec, P. \& Veberic, R. 2012. Late prohexadione-calcium application on maturing apple cv. 'Braeburn' fruit reduces anthocyanins and alters the phenolic content. Europen Journal of Horticultural Science 77(4): 154-162.

Borzouei, A., Kafi, M., Akbari-Ghogdi, E. \& Mousavi-Shalmani, M. 2012. Long term salinity stress in relation to lipid peroxidation, super oxide dismutase activity and proline content of salt sensitive and salt-tolerant wheat cultivars. Chilean Journal of Agricultural Research 72(4): 476-482.

Bremner, J.M. 1965. Total nitrogen. In Methods of Soil Analysis, part 2, edited by Black, C.A. Madison, Wisconsin: American Society of Agronomy. pp. 1149-1178.

Brown, A. 2007. Understanding Food Principles and Preparation. Boston: Cengage Learning.

Chettri, M.K., Cook, C.M., Vardaka, E., Sawidis, T. \& Lanaras, T. 1998. The effect of $\mathrm{Cu}, \mathrm{Zn}$ and $\mathrm{Pb}$ on the chlorophyll content of the lichens Cladonia convoluta and Cladonia rangiformis. Environmental and Experimental Botany 39(1): $1-10$.

Demir, K. \& Başak, H. 2008. Applications that provide growth control in vegetable seedlings. Seed Congress, Cappadocia. pp. 207-210.

De Saint Germain, A., Ligerot, Y., Dun, E.A., Pillot, J.P., Ross, J.J., Beveridge, C.A. \& Rameau, C. 2013. Strigolactones stimulate internode elongation independently of gibberellins. Plant Physiology 163(2): 1012-1025.

Dragisic-Maksimovic, J.J., Poledica, M.M., Radivojevi, D.D. \& Milivojevic, J.M. 2017. Enzymatic profile of 'Willamette' raspberry leaf and fruit affected by prohexadione-Ca and young canes removal treatments. Journal of Agricultural and Food Chemistry 65(24): 5034-5040.

Edge, R. \& Truscott, T.G. 2018. Singlet oxygen and free radical reactions of retinoids and carotenoids - A review. Antioxidants 7(1): 5 .

El-Ghorab, A.H., El-Massry, K., Alsohaimi, I.H., Hamza, M., Shaheen, M.S., Bekheta, M.A., Anees, A.K., Imran, M. \& El-sherif, M.A. 2019. The impact of some bioregulators on growth, chemical characters and radical scavenging properties of onion volatile oil. Pakistan Journal Agricultural Science 56(4): 828-838.

Fard, J.R., Kafi, M. \& Naderi, R. 2015. The enhancement of drought stress tolerance of kentucky bluegrass by prohexadione-calcium treatment. Journal of Ornamental Plants 5(4): 197-204.

Freitas, S.T., Jiang, C.Z. \& Mitcham, E.J. 2012. Mechanisms involved in calcium deficiency development in tomato fruit in response to gibberellins. Journal of Plant Growth Regulation 31(2): 221-234.

Ghiasi, N. \& Razavi, F. 2013. Impact of postharvest prohexadione calcium treatment on PAL activity in tomato fruit in response to chilling stress. Iranian Journal of Plant Physiology 4(1): 865-871.

Gül, A., Tüzel, İ.H., Okur, B., Tuncay, Ö., Aykut, N. \& Engindeniz, S. 2000. Cucumber Cultivation with Soilless 
Agriculture Technique in Greenhouse. Scientific and Technological Research Institution of Turkey (TUBITAK).

Kacar, B. \& İnal, A. 2008. Plant analysis. Nobel Pres. 1241: 891.

Kang, S.M., Kim, J.T., Hamayun, M., Hwang, I.C., Khan, A.L., Kim, Y.H., Lee, J.H. \& Lee, I.J. 2010. Influence of prohexadione-calcium on growth and gibberellins content of Chinese cabbage grown in alpine region of South Korea. Scientia Horticulturae 125(2): 88-92.

Kaptan, M.A. \& Aydın, M. 2007. Effects of different nitrogen doses on yield and some quality parameters of cucumber cultivation in soilless culture. Journal of Adnan Menderes University Agricultural Faculty 4(1-2): 77-81.

Kim, H.M., Lee, H.R., Kang, J.H. \& Hwang, S.J. 2019. Prohexadione-calcium application during vegetative growth affects growth of mother plants, runners, and runner plants of Maehyang strawberry. Agronomy 9(3): 155.

Kim, H.Y., Lee, I.J., Hamayun, M., Kim, J.T., Won, J.G., Hwang, I.C. \& Kim, K.U. 2007. Effect of prohexadione-calcium on growth components and endogenous gibberellins contents of rice (Oryza sativa L.). Journal of Agronomy and Crop Science 193(6): 445-451.

Kim, Y.H., Khan, A.L., Hamayun, M., Kim, J.T., Lee, J.H., Hwang, I.C., Yoon, C.S. \& Lee, I.J. 2010. Effects of prohexadione calcium on growth and gibberellins contents of Chrysanthemum morifolium R. cv Monalisa White. Scientia Horticulturae 123(3): 423-427.

Lichtenthaler, H.K. \& Wellburn, A.R. 1983. Determinations of total carotenoids and chlorophylls $a$ and $b$ of leaf extracts in different solvents. Biochemical Society Transctions 11(5): 591-592.

Omran, R.G. 1980. Peroxide levels and the activities of catalase, peroxidase, and indoleacetic acid oxidase during and after chilling cucumber seedlings. Plant Physiology 65(2): 407408.

Özbay, N. \& Süslüoğlu, Z. 2016. Assessment of growth regulator prohexadione calcium as priming agent for germination enhancement of pepper at low temperature. The Journal of Animal and Plant Sciences 26: 1652-1658.
Özbay, N. \& Ergun, N. 2015. Prohexadione calcium on the growth and quality of eggplant seedlings. Pesquisa Agropecuária Brasileira 50(10): 932-938.

Poledica, M.M., Milivojevic, J.M., Radivojevic, D.D. \& Maksimovic, J.J.D. 2012. Prohexadione-Ca and young cane removal treatments control growth, productivity, and fruit quality of the Willamette raspberry. Turkish Journal Agriculture and Forestry 36(6): 680-687.

Rademacher, W., Saarloos, K., Garuz-Porte, J.A., Riera Forcades, F., Senechal, Y., Andreotti, C., Sinelli, F., Sabatini, E. \& Costa, G. 2004. Impact of prohexadione-Ca on the vegetative and reproductive performance of apple and pear trees. European Journal of Horticultural Science 69(6): 221-228.

Spinelli, F., Speakman, J.B., Rademacher, W., Halbwirth, H., Stich, K. \& Costa, G. 2005. Luteoforol, a flavan 4-ol, is induced in pome fruits by prohexadione-Ca and shows phytoalexin-like properties against Erwinia amylovora and other plant pathogens. Europen Journal of Plant Pathology 112(2): 133-142.

Ugur, A. \& Kavak, S. 2007. The effects of PP 333 and CCC on seed germination and seedling height control of tomato. Acta Horticulturae 729: 205-208.

Zhang, Y.P., Jia, F.F., Zhang, X.M., Qiao, Y.X., Shi, K., Zhou, Y.H. \& Yu, J.Q. 2012. Temperature effects on the reactive oxygen species formation and antioxidant defence in roots of two cucurbit species with contrasting root zone temperature optima. Acta Physiologiae Plantarum 34(2): 713-720.

Kırşehir Ahi Evran University

Faculty of Agriculture

Department of Horticulture

Turkey

*Corresponding author; email: hbasak@ahievran.edu.tr

Received: 8 August 2020

Accepted: 19 December 2020 